\title{
Serum and tissue protein binding and cell surface properties of Staphylococcus lugdunensis
}

\author{
MARIANNE PAULSSON, ANN-CATHRINE PETERSSON and ÅSA LJUNGH*
}

Department of Medical Microbiology, University of Lund, Sölvegatan 23, S-22362 Lund, Sweden

\begin{abstract}
Summary. Eleven strains of Staphylococcus lugdunensis from different clinical sources were investigated for their ability to bind ${ }^{125}$ I-labelled collagen $(\mathrm{Cn})$ type I and IV, fibronectin $(\mathrm{Fn})$, vitronectin $(\mathrm{Vn})$, laminin $(\mathrm{Lm})$, fibrinogen $(\mathrm{Fg})$, thrombospondin, plasminogen (glu- and lysform) and human IgG. All the strains bound these proteins, although a higher degree of binding was obtained for $\mathrm{Cn}$ types I and IV and IgG with mean values of $36 \%, 32 \%$ and $26 \%$ binding. respectively. In tests with proteins immobilised on latex beads in a particle agglutination assay, eight of the 11 strains bound $\mathrm{Cn}$ type I and seven bound Fg, whereas no strain bound immobilised IgG. Binding to immobilised Cn-I, Fg, Lm and Vn was abolished when the bacterial cells were treated with proteases or heat, indicating cell-surface receptors with protein characteristics. Cell-surface extracts of S. lugdunensis 2342 were able to totally inhibit binding of the homologous strain and $S$. aureus Cowan 1 to latex-immobilised proteins $\mathrm{Cn}-\mathrm{I}, \mathrm{Lm}, \mathrm{Vn}, \mathrm{Fn}$ and Fg. The binding of ${ }^{125} \mathrm{I}$-labelled $\mathrm{Cn}$ IV by $S$. lugdunensis 2342 , was heat sensitive, whereas the binding to $S$. aureus Cowan 1 was heat resistant. The strains gave negative results in tests for the presence of protein A with a $S$. aureus protein A gene probe and with sensitised red blood cells. No production of heat-stable nuclease (TNase) could be detected by monoclonal antibodies against TNase or by the polymerase chain reaction with an oligonucleotide sequence from $S$. aureus $\mathrm{TN}$ ase as primer. When the cell surface characters of the $S$. lugdunensis strains were studied, five were found to be hydrophobic and negatively charged, four hydrophilic and positively charged and two hydrophobic with positive net charge.
\end{abstract}

\section{Introduction}

Coagulase-negative staphylococci (CNS) are well recognised as opportunist pathogens causing infections in neonates and neutropenic patients. ${ }^{3}$ They are the most important pathogens in infections associated with intravascular catheters and grafts, peritoneal catheters and prostheses in various organs. ${ }^{2}$ With the recent description of two new species of CNS, Staphylococcus lugdunensis and $S$. schleiferi ${ }^{3}$ there are at present 24 species of CNS. S. epidermidis, S. haemolyticus and $S$. saprophyticus are the species isolated most frequently from human infections. ${ }^{1}$

Coagulase-positive staphylococci, i.e., S. aureus, are more virulent than CNS. ${ }^{1}$ Numerous studies have focused on presumptive virulence factors of $S$. aureus, and latterly on those of $\mathrm{CNS}^{4}$ Of these factors, only protein $\mathrm{A}$ and coagulase are consistently absent in CNS. The presence of heat-stable nuclease is characteristic of coagulase-positive staphylococci but has not been ascribed any role in pathogenicity. ${ }^{1}$ All other toxins. enzymes and outer-membrane proteins of $S$. aurcus have been detected in CNS strains with varying

Received 9 April 1992: accepted 18 June 1992.

* Correspondence should be sent to Dr $\AA$. Ljungh. frequency. ${ }^{5.6}$ Production of extracellular polysaccharide material, "slime", is more prominent in CNS than in S. aureus, and slime has been discussed as an important virulence factor of CNS in biomaterialassociated infections. ${ }^{7}$ This has been an area of controversy. ${ }^{8}$

S. lugdunensis was originally described as a cause of endocarditis. ${ }^{9,10}$ Subsequent studies have shown that $S$. lugdunensis forms part of the normal skin flora but is frequently isolated from endocarditis, arthritis or soft tissue infections, i.e., S. lugdunensis appears to be more virulent than other CNS species. ${ }^{11.12}$ This study was undertaken to investigate presumptive virulence factors of $S$. lugdunensis strains isolated from various kinds of infections and from normal skin, particularly for factors which may influence the initial adhesion to host tissue - binding to connective tissue and serum proteins, cell-surface hydrophobicity, and net cellsurface charge.

\section{Materials and methods}

\section{Bacterial strains and culture media}

Eleven strains of $S$. lugdunensis were isolated from human infections and typed according to the methods 


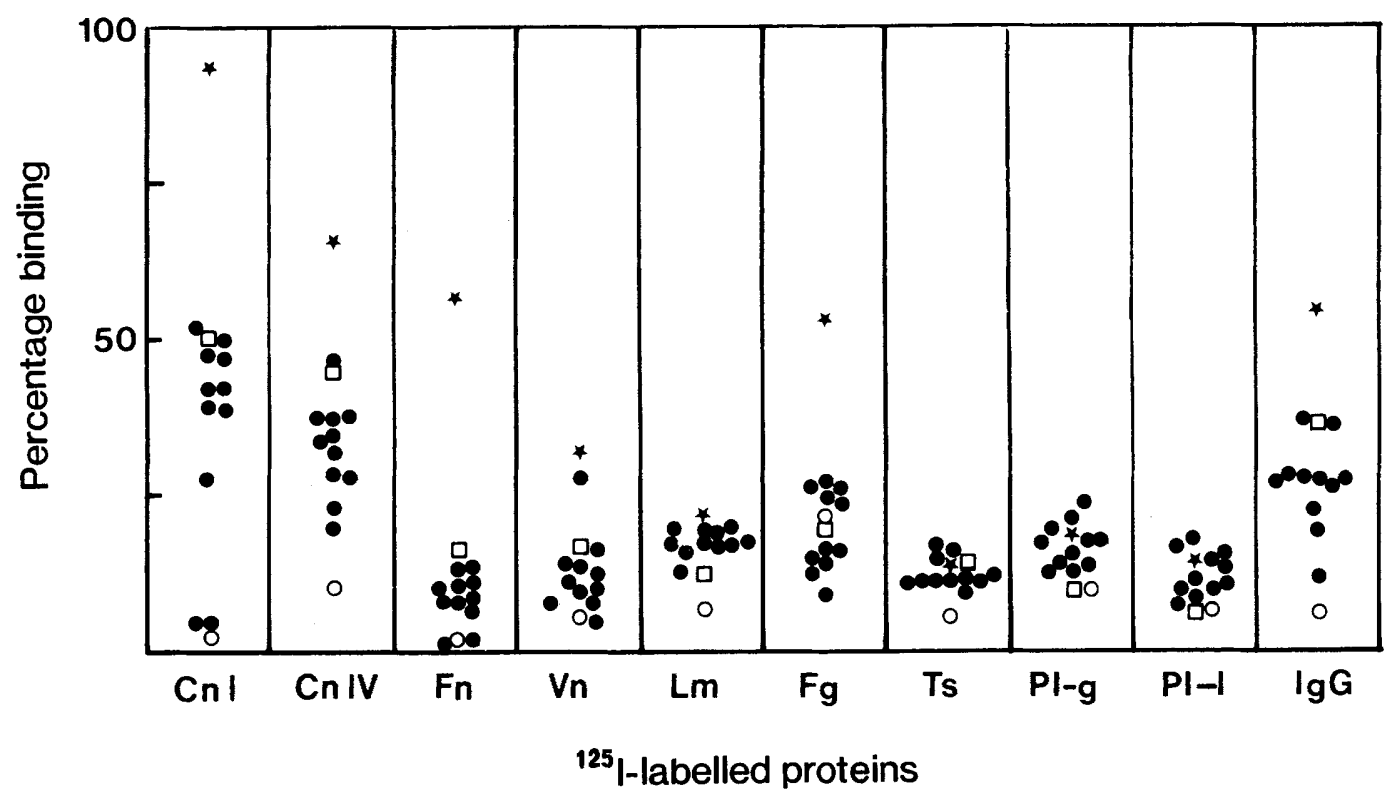

Fig. 1. Binding of ${ }^{125} \mathrm{I}$-labelled serum and tissue proteins to strains of $S$. lugdunensis $(\bullet), S$. aureus Cowan $1(\star), S$. haemolyticus E2498/86 $(\square)$ and S. epidermidis $3380(0)$.

of Freney et al. ${ }^{3}$ with an in-house panel of tests for ornithine decarboxylase, arginine dihydrolase and urease, nitrate reduction, acetoin production, acid production from mannose, sucrose, trehalose, mannitol and xylose, as well as anaerobic growth in semisolid thioglycollate broth. The strains were tested further for coagulase with human plasma, and for clumping factor with an in-house preparation of human plasma, with Staphyslide ${ }^{\circledR}$ (bioMérieux, Lyon, France) in which fibrinogen is adsorbed to sheep erythrocytes, with Monostaph ${ }^{\circledR}$ (BioNor, Skien, Norway) in which fibrinogen and IgG are adsorbed to monodispersed particles, and with Staphaurex ${ }^{\circledR}$ (Wellcome Diagnostics) in which fibrinogen and IgG are adsorbed to latex particles. Susceptibility to novobiocin $5 \mu \mathrm{g}$, polymyxin B $150 \mu \mathrm{g}$ and furazolidone $50 \mu \mathrm{g}$ was determined with Neo-Sensitab ${ }^{\circledR}$ (Rosco AS, Taastrup, Denmark). The strains were isolated from the following sites: 2342 and G2-89, blood (endocarditis); G6-87, blood (septicaemia); 49/91, bone marrow (osteomyelitis); SÅ, knee joint (arthritis); G587, peritoneal fluid (peritonitis); G58-88 and A251, wound infections; G66-68, suppurating axillary lymph node; and G3A and G16-89, normal skin.

S. aureus Cowan 1, Wood 46, V8 and ATCC 29213, $S$. haemolyticus E2498 and S. epidermidis 3380 were used as control strains. Bacterial strains were cultured on blood agar with horse erythrocytes $4 \% \mathrm{v} / \mathrm{v}$ for $24 \mathrm{~h}$ at $37^{\circ} \mathrm{C}$.

\section{Iodine-labelled protein binding assay}

The method has been described previously. ${ }^{13}$ Washed bacterial cells were suspended in $0.07 \mathrm{M}$ phosphate-buffered saline (PBS), $\mathrm{pH} 7 \cdot 2$, at a concentration of $5 \times 10^{9}$ cells $/ \mathrm{ml}$, and $100 \mu$ lof bacterial suspension was incubated with $50 \mu$ of ${ }^{125}$ I-labelled protein $\left(3 \times 10^{4} \mathrm{cpm}\right)$ in PBS with bovine serum albumin (BSA) $1 \%$ for $1 \mathrm{~h}$ at $20^{\circ} \mathrm{C}$. After washing with PBS-Tween $0 \cdot 1 \%$, the radioactivity of the pellet was measured, and the percentage binding was calculated. Less than $5 \%$ binding was considered to be a negative result.

Inhibition of binding of soluble proteins was studied by pre-incubation of bacterial cells with purified proteins $\left(100 \mu \mathrm{l} / \mathrm{ml}, 30 \mathrm{~min}, 20^{\circ} \mathrm{C}\right)$, after which binding of labelled protein was assayed as above.

\section{Particle agglutination assay $(P A A)$}

Proteins were immobilised on latex particles $(0.8 \mu \mathrm{m})$ as described previously. ${ }^{14}$ After adsorption of proteins to $1 \mathrm{ml}$ of latex, the mixtures were centrifuged $\left(9200 \mathrm{~g}, 5 \mathrm{~min}, 4^{\circ} \mathrm{C}\right)$, and the pellets were resuspended in $2 \mathrm{ml}$ of glycine buffer $(0.17 \mathrm{M}$ glycine- $\mathrm{NaOH}$, $\mathrm{pH} 8.2$ ) with ovalbumin $0.01 \%$ and merthiolate $0.01 \%$. The suspensions were kept at $4^{\circ} \mathrm{C}$. The PAA was performed on glass slides as described previously. ${ }^{14}$ The reactions were scored after observation for $2 \mathrm{~min}$ and given a numerical value: strongly positive $=3$, moderate $=2$, weakly positive $=1$, and no visible agglutination $=0 .{ }^{14}$ Strains were tested for auto-aggregation by mixing one drop of bacterial cell suspension with one drop of Pp-buffer. ${ }^{14}$

\section{Heat treatment}

Suspensions $(1 \mathrm{ml})$ of bacterial cells were heated at $80^{\circ} \mathrm{C}$ for $10 \mathrm{~min}$ and chilled rapidly.

\section{Extraction of cell-surface components}

Cells of S. aureus Cowan 1, and S. lugdunensis 2342 
Table I. Reactions of $11 \mathrm{~S}$. lugdunensis strains in four methods designed to detect clumping factor

\begin{tabular}{|c|c|c|c|c|}
\hline \multirow{2}{*}{ Strain no. } & \multicolumn{4}{|c|}{ Reaction in tests with } \\
\hline & $\mathrm{Fg}$ & Staphaurex & Staphyslide & Mono-Staph \\
\hline 2342 & + & + & + & $(+)$ \\
\hline $\mathrm{SÅ}$ & + & + & + & + \\
\hline $\mathrm{G} 3 \mathrm{~A}$ & - & - & - & - \\
\hline G5-87 & + & + & + & $(+)$ \\
\hline G2-89 & - & - & - & - \\
\hline G6-87 & + & + & + & $(+)$ \\
\hline G16-89 & + & + & + & $(+)$ \\
\hline G58-88 & $\ldots$ & - & - & - \\
\hline G66-88 & + & + & + & $(+)$ \\
\hline $49 / 91$ & - & - & - & - \\
\hline A251 & - & - & - & - \\
\hline Cowan 1 & + & + & + & + \\
\hline E2498 & - & - & - & - \\
\hline
\end{tabular}

$(+)$, Weak reaction.

(c. $1 \mathrm{~g}$ wet weight) were washed twice in Pp-buffer, and the cell-surface proteins were extracted with $1.5 \mathrm{ml}$ of $1 \mathrm{M} \mathrm{LiCl}, \mathrm{pH} 5 \cdot 0$, at $45^{\circ} \mathrm{C}$ for $2 \mathrm{~h}$. After centrifugation at $9750 \mathrm{~g}$ for $60 \mathrm{~min}$ the supernates were dialysed against $0.02 \mathrm{M}$ ammonium bicarbonate with $1 \mathrm{~mm}$ EDTA, pH 8.4, for $24 \mathrm{~h}$ at $4^{\circ} \mathrm{C}$. The extracts were centrifuged for $60 \mathrm{~min}$ at $9750 \mathrm{~g}$ and supplemented with $1 \mathrm{mM}$ phenylmethylsulphonylfluoride (PMSF). The protein content was 100 and $95 \mu \mathrm{g} / \mathrm{ml}$ for $S$. aureus Cowan 1 and $S$. lugdunensis 2342 respectively, as determined by BioRad micro-assay (BioRad, Richmond, CA, USA). The extracts were stored at $-20^{\circ} \mathrm{C}$ until required.

\section{Particle agglutination inhibition assay}

Bacterial cell suspensions were incubated with purified proteins $\left(100 \mu \mathrm{g} / \mathrm{ml}, 30 \mathrm{~min}, 20^{\circ} \mathrm{C}\right)$ before PAA was performed.

In another series of experiments, bacterial cellsurface extracts were incubated with equal volumes of coated latex beads $\left(30 \mathrm{~min}, 20^{\circ} \mathrm{C}\right)$ and then mixed with bacterial cells. Agglutination was recorded after $2 \mathrm{~min}$ and compared to agglutination with untreated coated latex beads.

\section{Protein A determination}

The production of protein A in 11 strains of $S$. lugdunensis was assayed with sensitised sheep erythrocytes $3 \%$ on glass slides as described previously, ${ }^{15}$ and in a tube agglutination test with readings taken after incubation at $37^{\circ} \mathrm{C}$ for $2 \mathrm{~h}$, and at $4^{\circ} \mathrm{C}$ for $18 \mathrm{~h} . S$. aureus ATCC 29213 and V8 were used as positive controls and S. aureus Wood 46 as negative control.

$S$. lugdunensis strains were hybridised with a DNA gene probe derived from $S$. aureus 8325-4 containing the whole protein A gene. ${ }^{16}$ Hybridisation was performed in a dot-blot assay under stringent conditions with $S$. aureus Cowan 1 and $8325-4$ as positive controls.

\section{Heat-stable (thermo) nuclease production}

The production of thermo-nuclease (TNase) was determined with monoclonal antibodies (MAbs) against TNase, ${ }^{17}$ and by the polymerase chain reaction (PCR) with an oligonucleotide sequence from $S$. aureus TNase as primer. ${ }^{18}$

\section{Partitioning in aqueous two-phase systems}

An aqueous polymer two-phase system containing PEG $60007 \cdot 13 \% \mathrm{w} / \mathrm{v}$ and dextran (Dx, MW 48000) $8.75 \% \mathrm{w} / \mathrm{v}$ in $0.015 \mathrm{M} \mathrm{NaCl}, \mathrm{pH} 6.8$ was prepared as described previously. ${ }^{19}$ To determine particle negative charge, the negatively charged Dx-sulphate was included at a concentration of $0.40 \% \mathrm{w} / \mathrm{v}$, replacing an equivalent amount of Dx. Similarly, the positively charged DEAE-Dx at a concentration of $0.40 \%$ replaced an equal amount of Dx.

Hydrophobic affinity partitioning was performed by including monosubstituted PEG-palmitate, replacing an equal amount of PEG, and Dx-palmitate, replacing an equal amount of Dx in the two-phase system. ${ }^{19}$

Bacterial cell suspensions $\left(100 \mu \mathrm{l}, c .5 \times 10^{9}\right.$ cells $\left./ \mathrm{ml}\right)$ was added to $0.9 \mathrm{ml}$ of the phase systems, previously homogenised by stirring, and mixed by gentle shaking. The mixtures were allowed to separate into phases for $1 \mathrm{~h}$ at $20^{\circ} \mathrm{C}$. The concentration of bacterial cells in the PEG-rich top phase and the Dx-rich bottom phase was then determined turbidimetrically at $540 \mathrm{~nm}$, and the recovery of cells in the bottom phase was expressed as a percentage of the original concentration of added cells. Differences in the hydrophobic and charge properties of the different bacterial strains are expressed as delta $\log \mathrm{G}$ which is defined as:

$$
\log G=\log \frac{G \text { value of Dx-sulph }{ }^{2} \text { or PEG-palm² system }}{G \text { value of the PEG-Dx system }}
$$

where $G=\frac{\text { percentage of cells in the bottom phase }}{\text { percentage of cells in the rest of the system }}$

\section{Chemicals}

Fibronectin (Fn) was purified from human plasma on gelatin-Sepharose according to Vuento and Vaheri, ${ }^{20}$ and vitronectin (Vn) from human ureatreated plasma on heparin-Sepharose. ${ }^{21}$ Vitrogen ${ }^{\mathbb{B}}$ (containing 95\% type I and 5\% type III collagen) and collagen type IV were purchased from Collagen Corporation, Palo Alto, CA, USA. Fibrinogen (Fg) and immunoglobulin $\mathrm{G}(\mathrm{IgG})$ were supplied by KABI, Stockholm, Sweden. Laminin (Lm), purified from an Engelberth-Holm-Swarm transplantable mouse tumour was kindly supplied by K. Valkonen, Oulu, Finland, ${ }^{22}$ thrombospondin (Ts) by J. Lawler, Boston, MA, USA, ${ }^{23}$ and plasminogen $(\mathrm{Pl})$ by $\mathrm{U}$. Hedner, Novo, Copenhagen, Denmark. ${ }^{24}$ Ovalbumin, PMSF, and dextran were purchased from Sigma. $\mathrm{LiCl}$ was from BDH, and latex beads from Difco. PEG 6000 


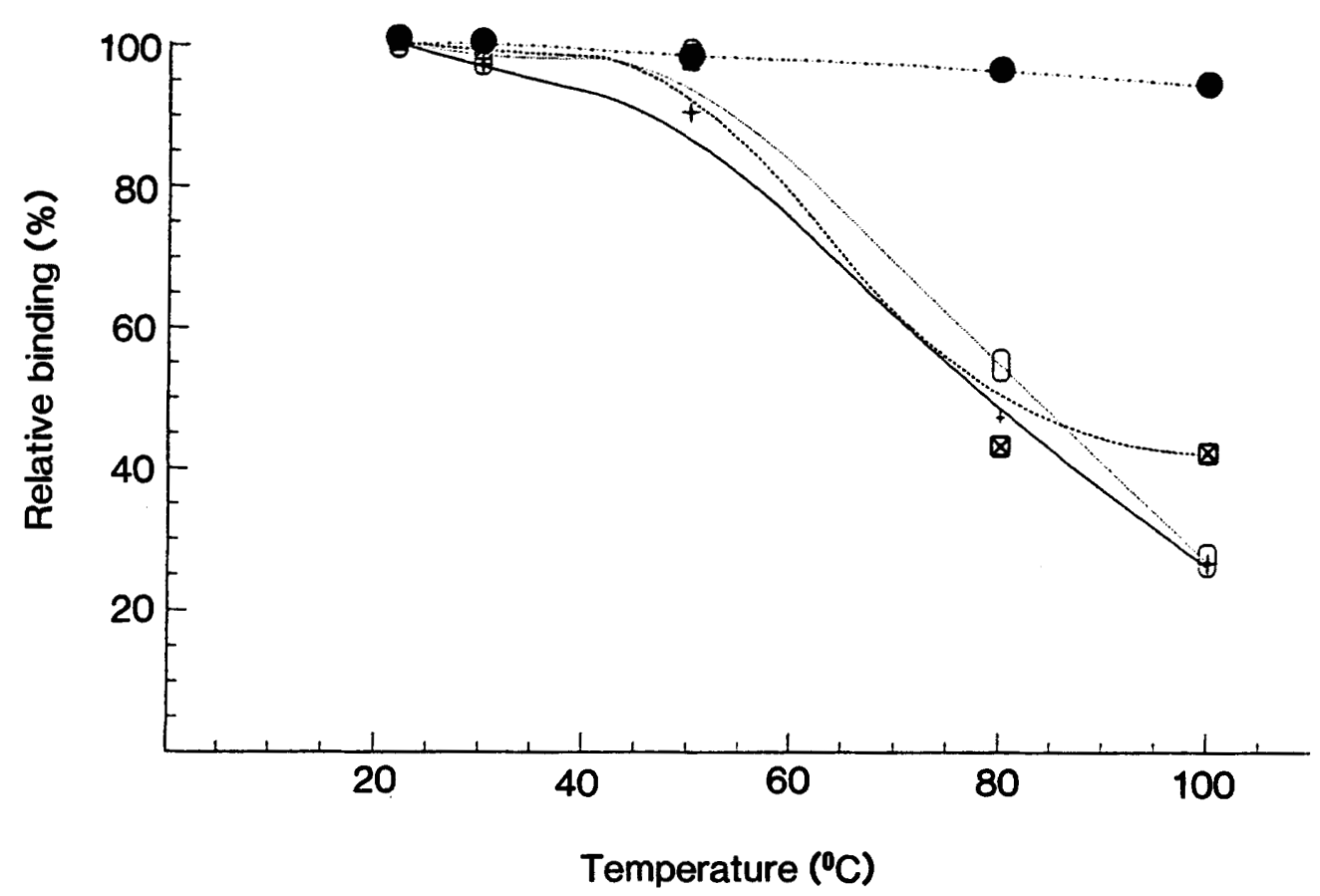

Fig. 2. The effect of heat treatment of $S$. lugdunensis cells on binding to ${ }^{125}$ I-labelled Cn-IV $(+-+)$ and laminin $(0 \cdots \ldots .0)$, and of $S$. aureus Cowan 1 cells on binding to ${ }^{125}$ I-labelled Cn-IV $(--\bullet)$ and laminin $(\varangle \ldots \ldots \otimes)$.

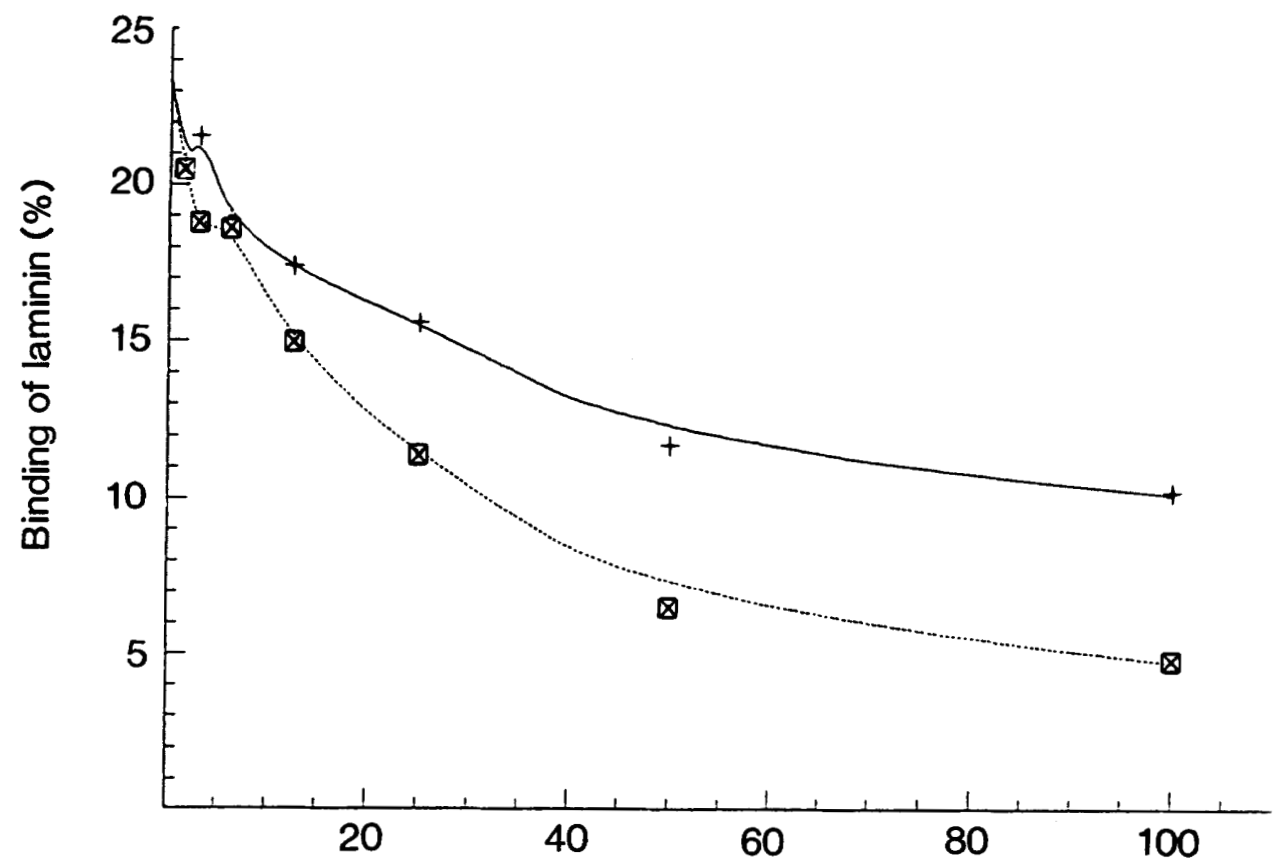

Concentration of extract $(\mu \mathrm{g} / \mathrm{ml})$

Fig. 3. Inhibition of laminin binding to $S$. lugdunensis 2342 with increasing amounts of LiCl-extract from $S$. lugdunensis $2342(+-—+)$ and S. aureus Cowan $1(\bigotimes \ldots . . . \otimes)$.

and merthiolate were from KEBO, Stockholm, Sweden and Iodobeads ${ }^{\circledR}$ from Pierce Chemical Co., Rockford, IL, USA. Dx-sulphate was from Pharmacia, Uppsala, Sweden, and PEG-palmitate from Aqueous Affinity, Arlöv, Sweden. DEAE-Dx and Dx-palmitate were kind gifts from G. Johansson, Lund. Agar bases were from Oxoid. All salts were of analytical grade.

\section{Results}

Binding to soluble proteins

Fig. 1 shows the binding profile of the 11 strains of $S$. lugdunensis and control strains. Most strains expressed medium binding of iodine-labelled collagen types I and IV and IgG (mean value 36,32 and $26 \%$ 
binding). Lower grades of binding were obtained with labelled Fg, Lm, Vn, Ts, Fn and Pl, both glu- and lysforms (mean values 19, 17, 12, 12, 12, 8 and $16 \%$ respectively). The positive control strains, $S$. aureus Cowan 1 and $S$. haemolyticus E2498 bound all the proteins tested whereas S. epidermidis 3380 either did not bind, or gave low grade binding with all the proteins tested.

\section{Binding to immobilised proteins}

When $\mathrm{Cn}$ type I and Fg were immobilised on latex beads. eight and seven strains, respectively, agglutinated coated latex beads. Two strains agglutinated immobilised Vn, and one strain Fn, Lm and gelatin. No strain agglutinated immobilised IgG or showed agglutination in the Staphaurex test. However, when $S$. lugdunensis strains were tested in the commercial tests according to the manufacturer's instructions, i.e., without prior washing of the cells, 6 of 11 strains gave positive results, although only weak reactions were noted with the Monostaph tests (table I).

\section{Characterisation of protein binding}

Binding of radiolabelled Lm by $S$. aureus Cowan 1 and $S$. lugdunensis 2342 was heat-sensitive whereas binding of Cn type IV by Cowan 1 was heat-resistant and by $S$. lugdunensis was heat-sensitive (fig. 2). Cellsurface extracts from strains Cowan 1 and 2342 inhibited $\mathrm{C} n$ binding and partly inhibited $\mathrm{Lm}$ binding to homologous as well as heterologous strains (fig. 3). These cell-surface extracts also inhibited agglutination of all immobilised proteins (table II). Pre-incubation
Table II. PAA-reaction of $S$. aureus Cowan 1 and $S$. lugdunensis 2342 after inhibition by cell-surface extracts of Cowan 1 and 2342

\begin{tabular}{|c|c|c|c|c|c|c|c|c|}
\hline \multirow{2}{*}{ Strain } & \multirow{2}{*}{ Extract } & \multicolumn{7}{|c|}{ PAA-reaction with } \\
\hline & & $\mathrm{CnI}$ & Fn & $\mathrm{Vn}$ & $\mathrm{Lm}$ & $\mathrm{Fg}$ & $\operatorname{IgG}$ & Staphaurex \\
\hline Cowan 1 & None & 3 & 3 & 2 & 2 & 3 & 2 & 3 \\
\hline Cowan 1 & Cowan 1 & 0 & 0 & 0 & 0 & 0 & 0 & 3 \\
\hline Cowan 1 & 2342 & 0 & 0 & 0 & 0 & 0 & 1 & 3 \\
\hline 2342 & None & 3 & 3 & 3 & 2 & 3 & 1 & 0 \\
\hline 2342 & 2342 & 0 & 0 & 0 & 0 & 0 & 0 & 0 \\
\hline 2342 & Cowan 1 & 0 & 0 & 0 & 0 & 0 & 0 & 0 \\
\hline
\end{tabular}

of S. lugdunensis strain 2342 with Cn inhibited subsequent binding of soluble but not of immobilised $\mathrm{Cn}$ (table II).

\section{Thermonuclease production}

None of the $11 S$. lugdunensis strains reacted with MAbs to TNase of $S$. aureus, or with the oligonucleotide sequence of $S$. aureus in PCR.

\section{Protein A production}

The positive control strains of $S$. aureus showed strong and rapid haemagglutination in the slide and tube agglutination tests whereas neither the $S$. lugdunensis strains nor the Wood 46 strain showed visible haemagglutination. None of the $S$. lugdunensis strains hybridised with the DNA gene probe for protein A of $S$. aureus; the control S. aureus strain did hybridise.

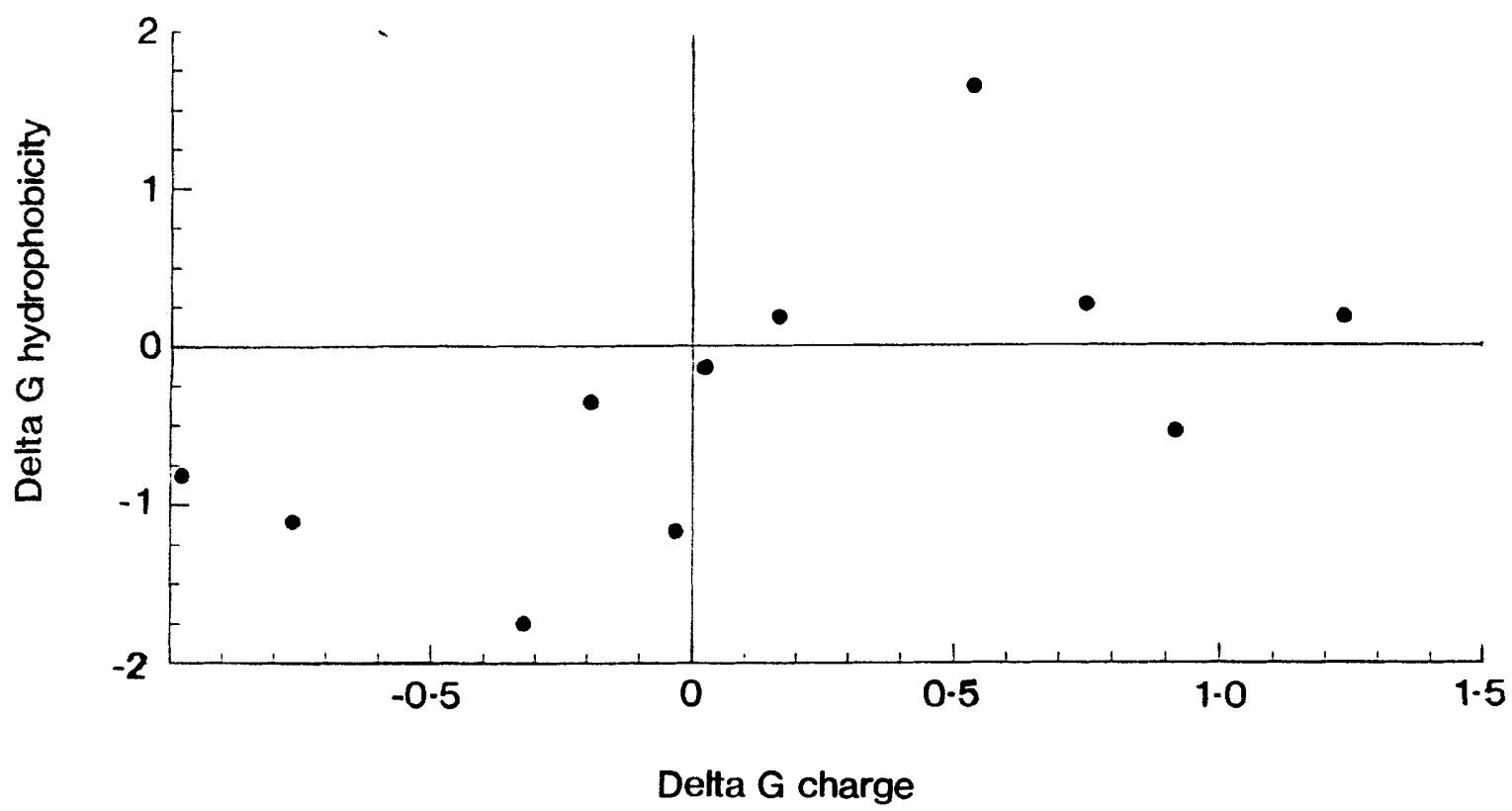

Fig. 4. Physicochemical surface properties of strains of S. Iugdunensis revealed by two-phase partioning system. Negative value of delta G hydrophobicity indicates hydrophobicity and negative value of delta $\mathrm{G}$ charge indicates negative surface charge. 


\section{Physicochemical characteristics of the cell surface}

There was no uniform pattern of either cell-surface hydrophobicity or of cell-surface charge in the strains tested. Three strains were neutral and four were positively charged, of which one expressed a hydrophilic cell surface. Four strains expressed a hydrophobic cell surface, of which three were negatively charged (fig. 4). There was no correlation between expression of cell-surface hydrophobicity, surface charge and protein binding.

\section{Discussion}

In a series of studies on experimental abscess formation, Lambe et al. have confirmed that $S$. lugdunensis is more virulent than other CNS species. ${ }^{25,26}$ However, factors contributing to the higher virulence have not been identified. It is interesting that $S$. lugdunensis strains are isolated from the same types of infections as $S$. aureus strains, i.e., deep or invasive infections, and infrequently from biomaterial-associated infections, where other CNS strains predominate. ${ }^{2}$

We have compared the expression of the ability to bind extracellular matrix (ECM) proteins and Fg and Vn by $S$. lugdunensis and $S$. aureus strains. Generally, $S$. lugdunensis expresses a higher ability to bind these proteins in a soluble form than other CNS species studied but a lower ability than that of $S$. aureus. Most strains expressed high binding to collagens, intermediate binding to $\mathrm{Fg}, \mathrm{Vn}$ and $\mathrm{Lm}$, and low binding to Fn. The difference in expression of binding to immobilised proteins is not so pronounced between the various species. The proteins included in this study are known to expose different domains when they are immobilised, compared to when they are in a soluble form. ${ }^{27,28} \mathrm{CNS}$ strains generally express higher binding to immobilised proteins ${ }^{29}$ than to soluble proteins, which is likely to be relevant in biomaterial-associated infections. Our preliminary characterisation of bind-

\section{References}

1. Kloos WE, Lambe DW. Staphylococcus. In: Balows A (ed) Manual of clinical microbiology, 5th edn. Washington, DC. American Society for Microbiology. 1991: 222-237.

2. Bisno AL, Waldvogel FA (eds). Infections associated with indwelling medical devices. Washington, DC, American Society for Microbiology. 1989.

3. Freney J, Brun Y, Bès M et al. Staphylococcus lugdunensis sp. nov. and Staphylococcus schleiferi sp. nov., two species from human clinical specimens. Int J Syst Bacteriol 1988; 38: $168-172$.

4. Novick RP (ed). Molecular biology of the staphylococci. New York, VCH Publications. 1990.

5. Gemmell CG. Exoproteins of coagulase-negative staphylococci as possible virulence factors. Zentralbl Bakteriol Mikrobiol Hyg Abt 1 1987; 16 Suppl 1: 93-102.

6. Wadström T, Rozgonyi $\mathrm{F}$, Ljungh $\AA$. Molecular pathogenesis of Staphylococcus saprophyticus infections. In: Svanborg- ing by $S$. lugdunensis to $\mathrm{Cn}$ and $\mathrm{Lm}$ indicates that the binding is mediated by surface-located proteinaceous structures.

The expression of $\mathrm{Fg}$ binding by $S$. lugdunensis strains is interesting from several aspects. First, Fg binding is usually co-expressed with coagulase production. However, S. lugdunensis strains do not produce coagulase. Secondly, there are probably a number of Fg-binding proteins in $S$. aureus. Since Fn, Vn and $\mathrm{Cn}$ binding proteins differ between $S$. aureus and CNS, ${ }^{29}$ it will be most interesting to investigate the relationship between $\mathrm{Fg}$-binding proteins in $S$. aureus and $S$. lugdunensis chemically and immunologically, and particularly to study whether the Fg-binding protein of S. lugdunensis is related to any of the Fgbinding proteins of $S$. aureus. Expression of Fg binding has been postulated as an important virulence factor of $S$. aureus in catheter-associated infections. ${ }^{30}$ Thirdly, Fg binding causes false positive reactions in some commercial $S$. aureus tests, which implies underdiagnosis of $S$. lugdunensis clinically.

In the original description of $S$. lugdunensis, the strains were described as unable to produce TNase. Our study confirms this and shows that $S$. lugdunensis strains lack the gene for TNase production. The DNA fragment used for detection of protein A contains the whole gene, i.e., both the IgG-binding and the cell-wall anchoring part. Hence the weak reaction of $\mathrm{IgG}$ binding of $S$. lugdunensis is not related to expression of part of protein A.

The findings presented in this study show that strains of $S$. lugdunensis are able to bind to soluble ECM proteins, $\mathrm{Vn}$ and $\mathrm{Fg}$ in a manner similar to strains of $S$. aureus rather than to other CNS strains. This may shed light on the pathogenesis of $S$. lugdunensis since the clinical spectrum of infections caused by $S$. aureus and $S$. lugdunensis is similar.

This study was supported by grants from the Swedish Board of Technical Development, NUTEK, and Faculty of Medicine, University of Lund. We thank E. Jakab for the purification of fibronectin and vitronectin, B. Guss and G. Brakstad for fruitful collaboration, D. W. Lambe and $\mathrm{Dr}$ W. Witte for sharing $S$. lugdunensis strains with us and T. Wadström for constructive criticism.

Edén C, Kass EH (eds) Host-parasite interactions. Chicago, University of Chicago Press. 1988: 214-218.

7. Christensen GD, Simpson WA, Younger JJ et al. Adherence of coagulase-negative staphylococci to plastic tissue culture plates: a quantitative model for the adherence of staphylococci to medical devices. J Clin Microbiol 1985; 22: 996-1006

8. Franson TR, Sheth NK, Menon L, Sohnle PG. Persistent in vitro survival of coagulase-negative staphylococci adherent to intravascular catheters in the absence of conventional nutrients. $J$ Clin Microbiol 1986; 24 : 559-561.

9. Etienne J, Pangon B, Leport C et al. Staphylococcus lugdunensis endocarditis. Lancet 1989; 1: 390.

10. Fleurette J, Bès M, Brun Y et al. Clinical isolates of Staphylococcus lugdunensis and Staphylococcus schleiferi: bacteriological characteristics and susceptibility to antimicrobial agents. Res Microbiol 1989; 140: 107-118.

11. Herchline TE, Ayers LW. Occurrence of Staphylococcus lugdunensis in consecutive clinical cultures and relationship 
of isolation to infection. $J$ Clin Microbiol 1991; 29: $419-421$.

12. Walsh B, Mounsey JP. Staphylococcus lugdunensis and endocarditis. J Clin Pathol 1990; 43: 171.

13. Paulsson M, Wadström $T$. Vitronectin and type I-collagen binding by Staphylococcus aureus and coagulase-negative staphylococci. FEMS Microbiol Lett 1990; 65: 55-62.

14. Naidu AS, Paulsson M, Wadström T. Particle agglutination assays for rapid detection of fibronectin, fibrinogen and collagen receptors on Staphylococcus aureus. J Clin Microbiol 1988; 26: 1549-1554.

15. Winblad S, Ericson C. Sensitized sheep red cells as a reactant for Staphylococcus aureus protein A. APMIS 1973; B 81: $150-156$

16. Guss B, Lindberg M, Uhlén $M$. The gene for staphylococcus protein A. In : Boyle MDP (ed) Bacterial immunoglobulinbinding proteins. London, Academic Press. 1990: 29 39.

17. Brakstad OG. Maeland JA. Generation and characterization of monoclonal antibodies against Staphylococcus aureus thermonuclease. APMIS 1989; 97: 166-174.

18. Brakstad OG, Aasbakk K. Maeland JA. Detection of Staphylococcus aureus by the polymerase chain reaction amplification of the nuc gene. Abstracts of the 4th European Congress of Clinical Microbiology and Infectious Diseases, Oslo, Norway; 1991.

19. Ascencio F, Aleljung P, Wadström T. Particle agglutination assay to identify fibronectin and collagen cell surface receptors and lectins in Aeromonas and Vibrio species. Appl Environment Microbiol 1990; 56: 1926-1931.

20. Vuento M. Vaheri A. Purification of fibronectin from human plasma by affinity chromatography under non-denaturing conditions. Biochem $J$ 1979; 183: 331-337.

21. Yatohgo $T$, Izumi $\mathbf{M}$, Kashiwagi $H$, Hayashi $M$. Novel purification of vitronectin from human plasma by heparin affinity chromatography. Cell Struct Funct 1988; 13: $281-292$
22. Valkonen $\mathrm{KH}$, Veljola J, Dagberg B, Uhlin BE. Binding of basement-membrane laminin by Escherichia coli. Mol Microbiol 1991; 5: 2133-2141.

23. Herrmann M, Suchard SJ, Boxer LA, Waldvogel FA, Lew PD. Thrombospondin binds to Staphylococcus aureus and promotes staphylococcal adherence to surfaces. Infect Immun 1991; 59: 279-288.

24. Kuusela P, Saksela O. Binding and activation of plasminogen at the surface of Staphylococcus aureus. Increase in affinity after conversion to the Lys form of the ligand. Eur $J$ Biochem 1990; 193: 759-765.

25. Lambe DW, Ferguson KP, Keplinger JL, Gemmell CG, Kalbfleisch JH. Pathogenicity of Staphylococcus lugdunensis, Staphylococcus schleiferi and three other coagulase-negative staphylococci in a mouse model and possible virulence factors. Can J Microbiol 1990; 36: 455-463.

26. Ferguson KP, Lambe DW, Keplinger JL, Kalbfleisch JH. Comparison of the pathogenicity of three species of coagulase-negative Staphylococcus in a mouse model with and without a foreign body. Can J Microbiol 1991; 37: $722-724$.

27. Grinnell F, Feld MK. Fibronectin adsorption on hydrophilic and hydrophobic surfaces detected by antibody binding and analyzed during cell adhesion in serum-containing medium. J Biol Chem 1982; 257: 4888-4893.

28. Wolff C, Lai C-S. Fluorescence energy transfer detects changes in fibronectin structure upon surface binding. Arch Biochem Biophys 1989; 268: 536-545.

29. Paulsson M, Ljungh $\AA$, Wadström T. Rapid identification of fibronectin, vitronectin, laminin and collagen cell surface binding proteins on coagulase-negative staphylococci by particle agglutination assays. $J$ Clin Microbiol 1992; 30 : 2006-2012.

30. Cheung AL, Fischetti VA. The role of fibrinogen in staphylococcal adherence to catheters in vitro. $J$ Infect Dis $1990 ; 161: 1177-86$. 